総＼cjkstart説

\title{
低侵襲性高力学的生体適合性生体用チタン合金
}

\author{
新家 光雄 \\ 東北大学金属材料研究所, $=980-8577$ 仙台市青葉区片平 2-1-1。
}

\section{Titanium Alloys with High Biological and Mechanical Biocompatibility}

\author{
Mitsuo Niinomi \\ Institute for Materials Research, Tohoku University, 2-1-1 Katahira Aoba-ku, Sendai 980-8577, Japan.
}

Received January 10, 2008

\section{SYNOPSIS}

$\beta$-type titanium alloys composed of non-toxic and allergy-free elements with low modulus are getting much attention for biomedical applications. The author has developed $\mathrm{Ti}-29 \mathrm{Nb}-13 \mathrm{Ta}-4.6 \mathrm{Zr}$ (TNTZ) where Nb, Ta, and $\mathrm{Zr}$ are non-toxic and allergy-free are elements showing low Young's modulus. Focusing on TNTZ, biological and mechanical biocompatibility including fatigue characteristics, fretting fatigue characteristics, and wear characteristics, functionalities such as super elastic and shape memory effect, and bioactive surface modification of low modulus titanium alloys with high biological and mechanical biocompatibility for biomedical applications are described.

\section{KEY WORDS}

titanium alloys, biomedical applications, biological biocompatibility, mechanical biocompatibility, low modulus

1 はじめに

金属系バイオマテリアルは, ステンレス鋼，コバルト $(\mathrm{Co})$ 合金, チタン $(\mathrm{Ti})$ およびチタン合金が主流であり, それらの 中でもチタンおよびチタン合金の生体適合性が最も優れてい る. チタン合金は, さらに耐食性, 比強度 (強度/密度) 等に も優れることから, 生体用としての需要が増加しているとと もに，その研究・開発も盛んとなっている. 現在, 実用化さ れているチタン合金は, Ti-6Al-4V ELI合金が主流であり, 生 体用合金の需要のほとんどを占めている。Ti-6Al-4V ELI 合 金は，現在までのところ，何ら支障を来たしているわけでは ないが, 元来航空機用等の一般構造用から生体用に転用され ていることから, 含有元素単体に注目して見ると, 生体為害 性を指摘されたバナジウム $(\mathrm{V})$ を含有している等問題点があ る.このような背景から，Vを生体為害性が指摘されておら ず, $\mathrm{V}$ と同じく $\beta$ 安定化元素であるニオブ $(\mathrm{Nb})$ や鉄 $(\mathrm{Fe})$ で置 き換えた Ti-6Al-7Nb 合金や Ti-5Al-2.5Fe 合金が開発されて いる.この中で, Ti-6Al-7Nb 合金の需要は, 徐々に増加して いるようである. その後, Vおよびアルミニウム $(\mathrm{Al})$ を除外 した Ti-15Sn-4Nb-2Ta-0.2Pd 合金や Ti-15Zr-4Nb-2Ta-0.2Pd 合金が開発されている，さらには，骨の弾性率 $(10-30 \mathrm{GPa})$
と類似する弾性率を有することを目指した低弾性率 $\beta$ 型チ夕 ン合金の開発がなされるようになっている.多くの低弾性率 $\beta$ 型チタン合金が開発されているが, それらの多くは, 無毒 性・非アレルギ一元素で構成されており, 生物学的生体適合 性と骨との力学的適合性(力学的生体適合性)の両者を考慮し た合金設計がなされている. 最近では, 生物学的生体適合性 および力学的生体適合性に加え, 機能性の付与も行われるよ うになっている.このような生体用チタン合金として, 著者 らは, Ti-29Nb-13Ta-4.6Z 合金 (TNTZ 合金) を開発し，その 実用化を目指して研究・開発を進めてきている，そこで，本 稿では, TNTZ 合金を中心とし, 生体用機能性低弾性率 $\beta$ 型 チタン合金に関しての研究・開発動向を紹介することとする.

\section{2 低侵襲性高生体力学的生体適合化合金設計}

先ずは, 基本的な低侵襲性 (ここでは生物学的生体適合性 を取り上げる) を考慮した合金設計のために細胞毒性および アレルギー性の低い合金元素の選択から始める.すなわち, 純金属等の細胞毒性, 生体組織親和性, 耐食性およびアレル ギー性に関する報告データ 1,2)を参考にすることになる。この ような報告例から, 最も生体為害性の低い $\mathrm{Ti}$ への合金元素と 
しては, $\mathrm{Nb}$, Taおよびジルコニウム $(\mathrm{Zr})$ が選択される.特に, 金属アレルギー性の点でニッケル $(\mathrm{Ni})$ の添加は, 回避される 傾向にあるが, 一般的なチタン合金では, これまでNiを添加 することはかなり限られた合金系であるので, 大きな問題点 とはならない。次に, 力学的生体適合性として, 最も優先さ れる弾性率の低下を考えた合金設計を行う必要がある.その 場合には， $\alpha$ おび $\alpha+\beta$ 型チタン合金よりも結晶構造の点で 弾性率が低い $\beta$ 型チタン合金とすることが有利である.なお， $\alpha$ 型チタン合金の主構成相である $\alpha$ 相は稠密六方晶 $(\mathrm{HCP})$ 構 造で最も原子が密に詰まった構造であり， $\beta$ 型チタン合金の 主構成相である $\beta$ 相怡体心立方晶 $(\mathrm{BCC})$ 構造で原子の詰まり 方が比較的粗である. したがって, $\beta$ 相安定化元素である $\mathrm{Nb}$ およびTaを多量に添加する方向となる. Zr は，通常中性元素

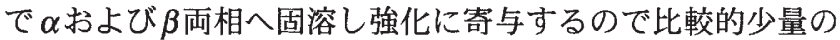
添加を考える. 以上のようなコンセプトで Ti-Nb-Ta- Zr 系低 弾性率 $\beta$ 型チタン合金の組成を決定するが，その場合 $\mathrm{DV}_{\alpha}-\mathrm{X}$ クラスター法に基付いて開発された $\mathrm{d}$ 電子合金設計法 ${ }^{3)}$ で決 定することが多くの実験試料を作製することなく決定できる ので簡便である．著者らは，この手法にて Ti-29Nb-13Ta$4.6 \mathrm{Zr}$ (TNTZ) 合金を提案し，寒用化を目指してその研究・開 発を進めてきている.これと同系の合金として, ほぼ同時期に Rack ら ${ }^{4)}$ によって発表された Ti-35Nb-7Zr-5Ta 合金がある. その後, Ti-36Nb-2Zr-3Ta-O 合金 ${ }^{5)}$ が開発されている.この 合金は民生用として開発されているが, 医療用への展開も主 張されている.

\section{3 生物学的生体適合性}

TNTZ合金，Ti-6Al-4V ELI合金およびSUS 316L ステンレ 又鋼の丸棒試験片を家鬼の大腿骨へ移植後 8 週での各試験片 と骨との界面の CMR を Fig. $1^{6}$ に示す。骨が試験片と直接接 触していない領域 (lucent line) が SUS 316L ステンレス鋼で最 も大きく, TNTZ合金で最も小さいことがわかり，TNTZ合金 の骨との生体親和性が最も良好であると判断される.

\section{4 力学的生体適合性}

4.1 低弾性率

低弾性率であることは，骨折の早期治癒，骨吸収の抑制や

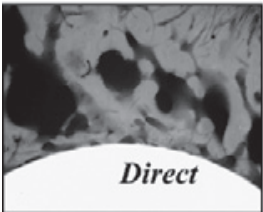

Ti-29Nb-13Ta-4.6Zr
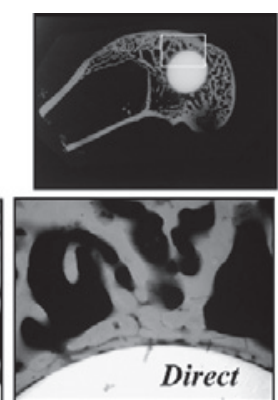

Ti-6Al-4V ELI
Observation of tissue reaction and bone formation

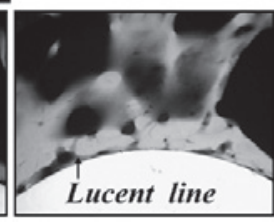

SUS 316L stainless steel
Fig.1 CMR photograph of boundary of each specimen.
良好な骨のリモデリングに有効であることが家鬼脛骨骨折モ デルへのTNTZ合金製髄内釘移植実験により確認されている》． また, 髄内釘を留置した脛骨と対照側の脛骨の曲げ強度に関 しても報告がなされている ${ }^{8)}$ ，すなわち，TNTZ合金，Ti-6Al4V ELI合金およびSUS 316Lステンレス鋼製髄内釷を家兔の 左脛骨に作成した骨折モデルに移植し， 1 年 4 ケ月〜 1 年 6 ケ 月後に屠殺し，野道内釷を引き拔き， 3 点曲げ強度を対照側で ある右側脛骨のそれと比較した例であり，その結果を Fig. $2^{8)}$ に示す. Ti-6Al-4V ELI合金およびSUS 316Lステンレス鋼製 髄内釷では，髄内釷留意側脛骨の 3 点曲げ強度が対照側脛骨 に比べて低くなる傾向にあるが，TNTZ合金製随内釘の場合 では髄内釗留意側脛骨の 3 点曲げ強度が対照僋脛骨に比べて 同等以上となる傾向にある. また, SUS 316Lステンレス鋼製 髄内釷では，骨組織の変化も報告されている7).

低弾性率であることが骨のリモデリングに大きく影響する ことは, やはり家鬼の脛骨骨折モデルに TNTZ合金, Ti-6Al4V ELI合金およびSUS 316Lステンレス鋼製骨折固定プレー 卜を移植し,その治癒状況を観察することでも示されている.

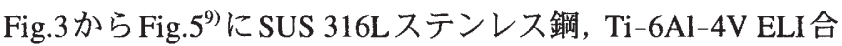
金およびTNTZ合金製骨折固定プレートを家鬼脛骨骨折モデ ルに移植した場合のX線による観察経過を示す. SUS 316Lス テンレス鋼製骨折固定プレートでは，7週目からプレート直 下で骨吸収が始まり，12週目でほとんどその骨が消失してい るように観察される. Ti-6Al-4V 合金製骨折固定プレートで は, 7週目からプレート直下で骨吸収が始まり，14週目でほ とんどその骨が消失しているように観察される。ささらに, TNTZ合金製骨折固定プレートでは, 10 週目でプレート直下 での骨吸収が始まり, 18週目でほとんどその骨が消失してい るように観察される。したがって，TNTZ合金製骨折固定プ レートでのプレート直下での骨吸収開始までの期間および消 失までの期間が最も長くなっており，低弾性率であることが 骨吸収をより抑制していると判断される。ささらに，TNTZ合 金製骨折固定プレート移植後44週目での骨折骨プレート中位 および遠位での横断面のCMRを Fig.69)に示す.この場合，骨 折固定プレートの中位および遠位にて髄腔を区切る骨組織が

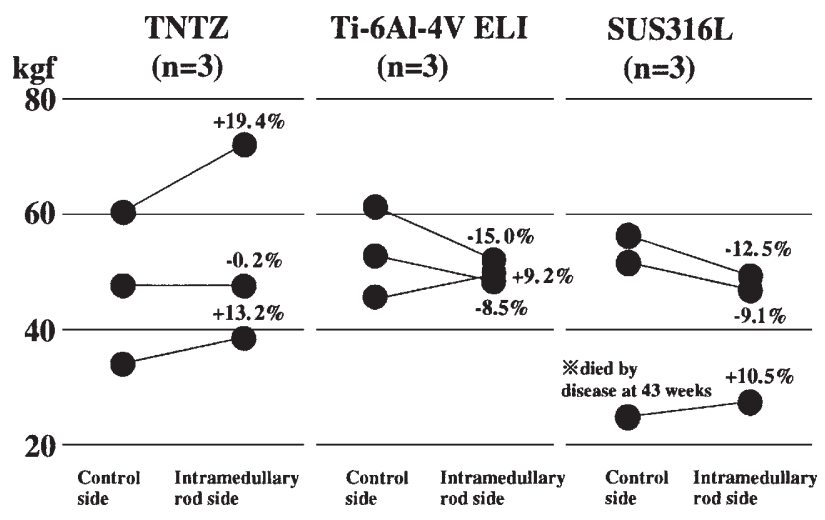

Fig.2 Three point bend strength: fracture load. 


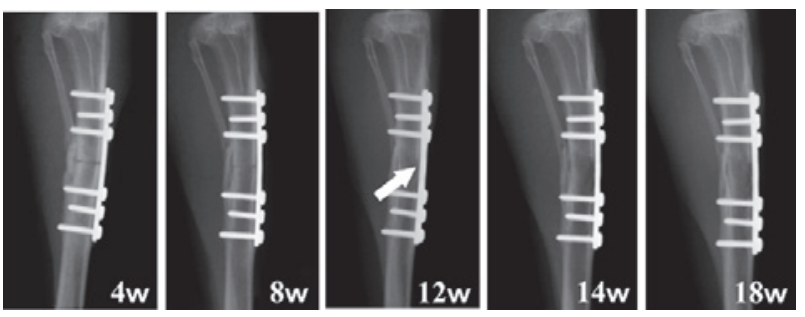

Fig.3 X-ray follow-up from 4 to 18 weeks after implantation for SUS $316 \mathrm{~L}$ stainless steel.
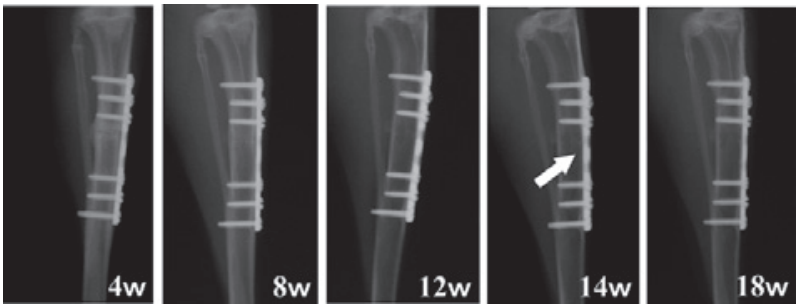

Fig.4 X-ray follow-up from 4 to 18 weeks after implantation for Ti-6Al-4V ELI.
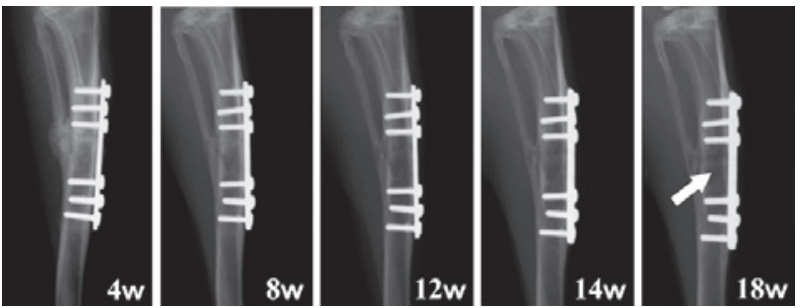

Fig.5 X-ray follow-up from 4 to 18 weeks after implantation for TNTZ.

観察され，かつ脛骨外径が拡大することが見出されている. Fig.6で, 内径を構成する骨形状は元の骨の形状に類似してい る.したがって，外径を構成する骨は，新たに形成された骨 と判断される。この現象は，TNTZ合金製骨折固定プレート の場合にのみ観察されている.このことから, 低弾性率であ るTNTZ合金製骨折固定プレートで応力に応じた骨のリモデ リングが生じていることがわかる，以上のように，低弾性率 であることは，骨の吸収の抑制やリモデリングに有効である ことがわかる.

4.2 疲労寿命

TNTZ合金は, $\beta$ 型チタン合金であることから，時効処理に より第2相を析出させ強化することにより疲労寿命を改善す ることが可能である. Fig. $7^{10}$ は, TNTZ合金を溶体化後, $573 \mathrm{~K}$, $673 \mathrm{~K}$ および $723 \mathrm{~K}$ の各温度で時効した場合の時効曲線であ る.いずれの時效温度でも時効時間の増加とともに硬さが増 大しており, 同じ時効時間では時効温度が高い程硬さが大き くなっている. これらの時効温度で覀時効 (UA), 最高時効 (PA) および過時効 (OA) の条件での疲労寿命 (S-N曲線) を調 べると,いずれの場合にも溶体化ままの状態に比べ, 疲労寿命 が增大している. 代表例として, 時效温度 $573 \mathrm{~K}$ および $723 \mathrm{~K}$ の場合のUA, PA およびOAの S-N曲線を Fig. 8 およびFig. $9^{10)}$

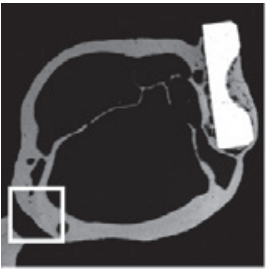

(a)

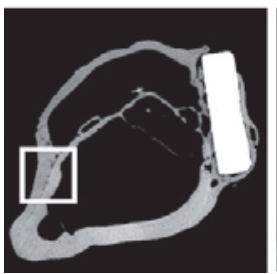

(a)

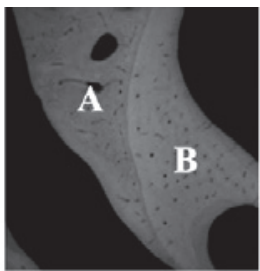

(b)

Middle

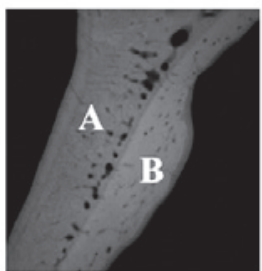

(b)

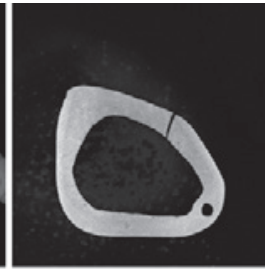

(c)

(c)

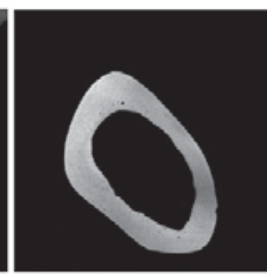

Fig.6 CMR of cross sections of middle and distal parts of fracture model made in tibia of rabbit fixed by bone plate made of TNTZ implanted for 44 weeks and control side tibia: (a) cross section of fracture model, (b) high magnification CMR of branched part of outer and inner formed bone, and (c) cross section of control side tibia.

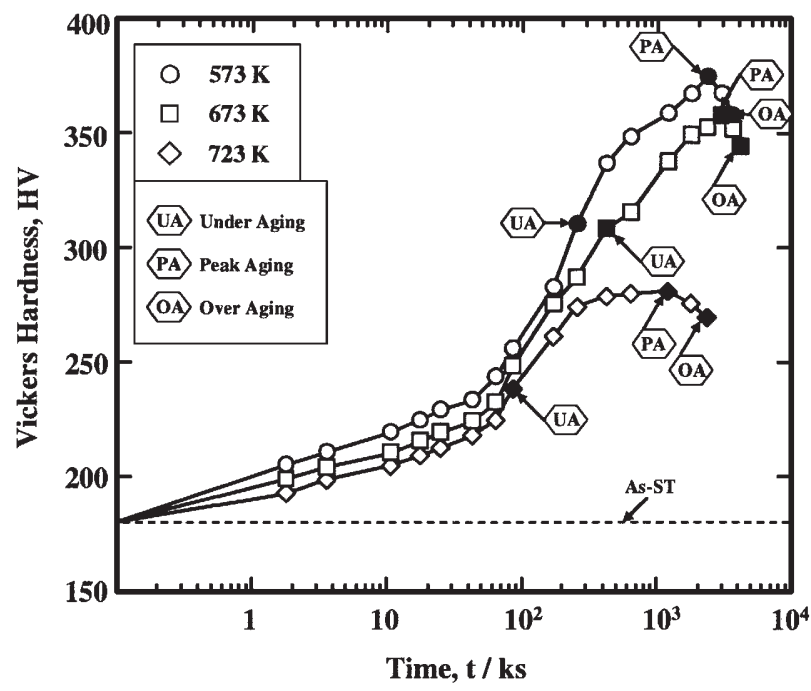

Fig.7 Relationship between Vickers hardness and aging time of TNTZ subjected to aging at $573 \mathrm{~K}, 673 \mathrm{~K}$ and $723 \mathrm{~K}$ after solution treatment.

に示す．これらの図中には，代表的な実用生体用チタン合金 である Ti-6Al-4V 合金の疲労限範囲を併記してある.いずれ の場合にも，疲労限は，Ti-6Al-4V 合金のそれの範囲に入っ ているが, $723 \mathrm{~K}$ の時効温度でのUA, PA およびOA 疲労寿命 の方が $573 \mathrm{~K}$ の時効温度での UA, PA およびOAより高く, Ti$6 \mathrm{Al}-4 \mathrm{~V}$ 合金の疲労限範囲の中位から上位に位置するように なっている.これらの時効条件での引張り特性を Fig.10 $10^{10)} に$ 示すが, $573 \mathrm{~K}$ の時効温度では, UAの場合を除き強度は上昇 しているが, 伸びが著しく低下している. S-N曲線は示して いないが， $673 \mathrm{~K}$ の時効温度では，強度上昇が著しいが，伸 


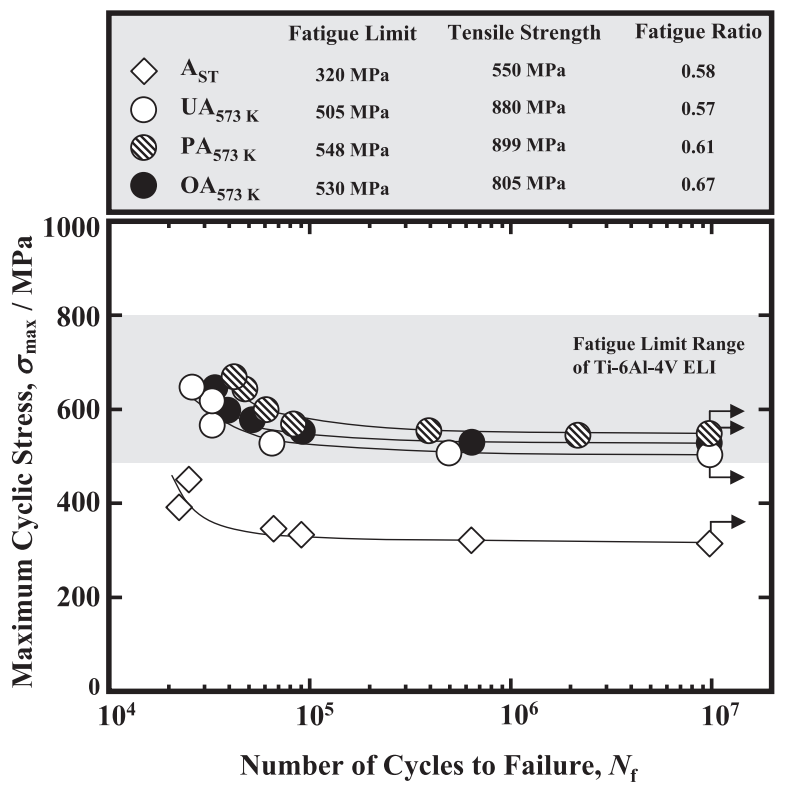

Fig.8 S-N curves of $\mathrm{A}_{\mathrm{ST}}$ (as-solutionized), $\mathrm{UA}_{573 \mathrm{~K}}, \mathrm{PA}_{573 \mathrm{~K}}$ and $\mathrm{OA}_{573 \mathrm{~K}}$ obtained from fatigue tests in air.

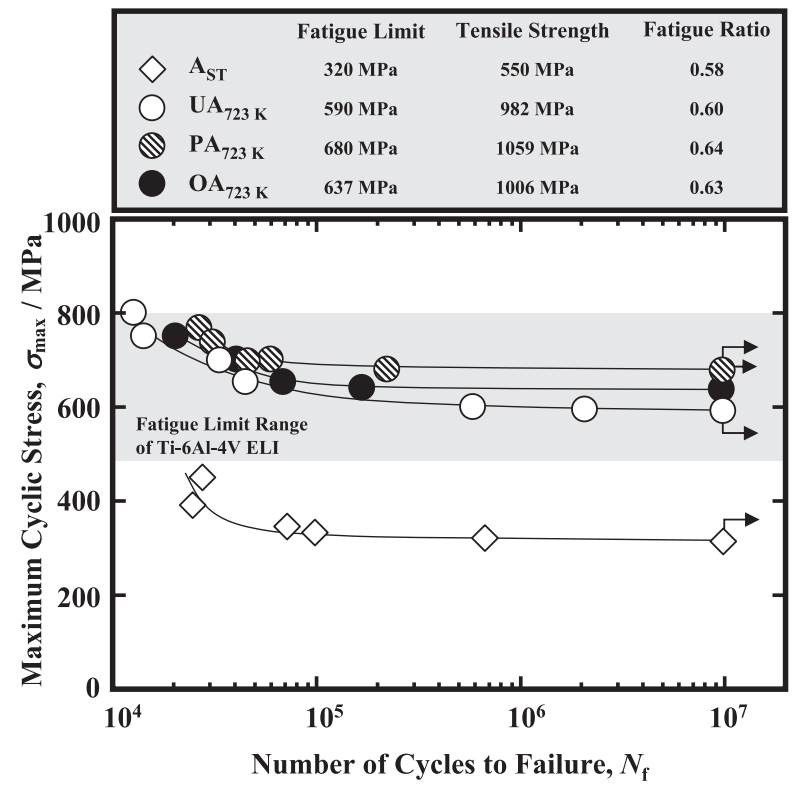

Fig.9 S-N curves of $A_{S T}$ (as-solutionized), $\mathrm{UA}_{723 \mathrm{~K}}, \mathrm{PA}_{723 \mathrm{~K}}$ and $\mathrm{OA}_{723 \mathrm{~K}}$ obtained from fatigue tests in air.

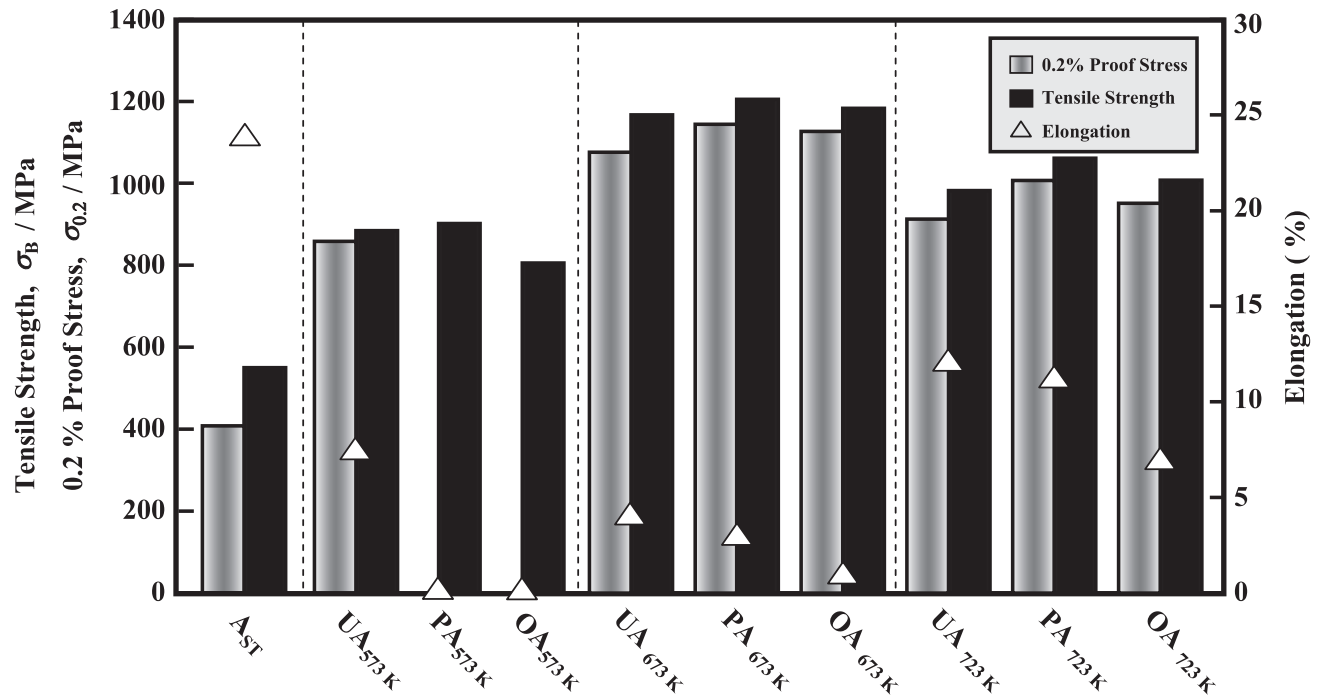

Fig.10 Tensile properties of TNTZ subjected to solution treatment and various aging treatments.

びがかなり小さいことが示されている. $723 \mathrm{~K}$ の時効温度で は, 強度が上昇し，伸びも大きく, 強度・延性バランスが良 い. 中でも, PA での強度・延性バランスが特に優れている. また, Fig.11 ${ }^{10)} に$ 弾性率を示すが, この場合の弾性率は, 約 $80 \mathrm{GPa}$ で時効により上昇はしているもののかなり低い值と

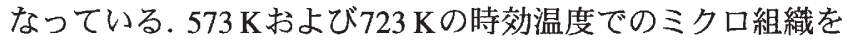
Fig.12 および Fig.13 ${ }^{10)}$ に示すが，前者では $\omega$ 相が，後者では $\alpha$ 相が $\beta$ 母相に析出している， $\omega$ 相の析出は，脆化傾向を増 すことがわかる。

さらに, 加工熱処理を駆使することによりさらに疲労寿命 を改善することが可能である．例えば，Fig.14 ${ }^{11}$ に模式的に 示す (溶体化+冷間強加工+時効)の加工熱処理を施すことに

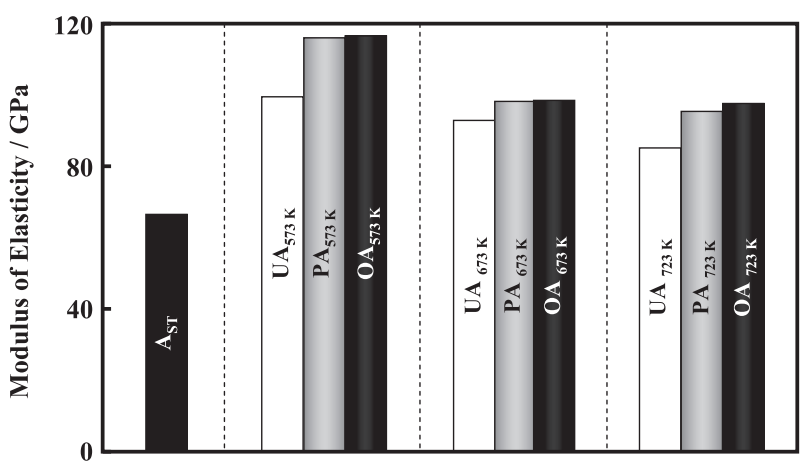

Fig.11 Modulus of elasticity of TNTZ subjected to various heat treatments. 

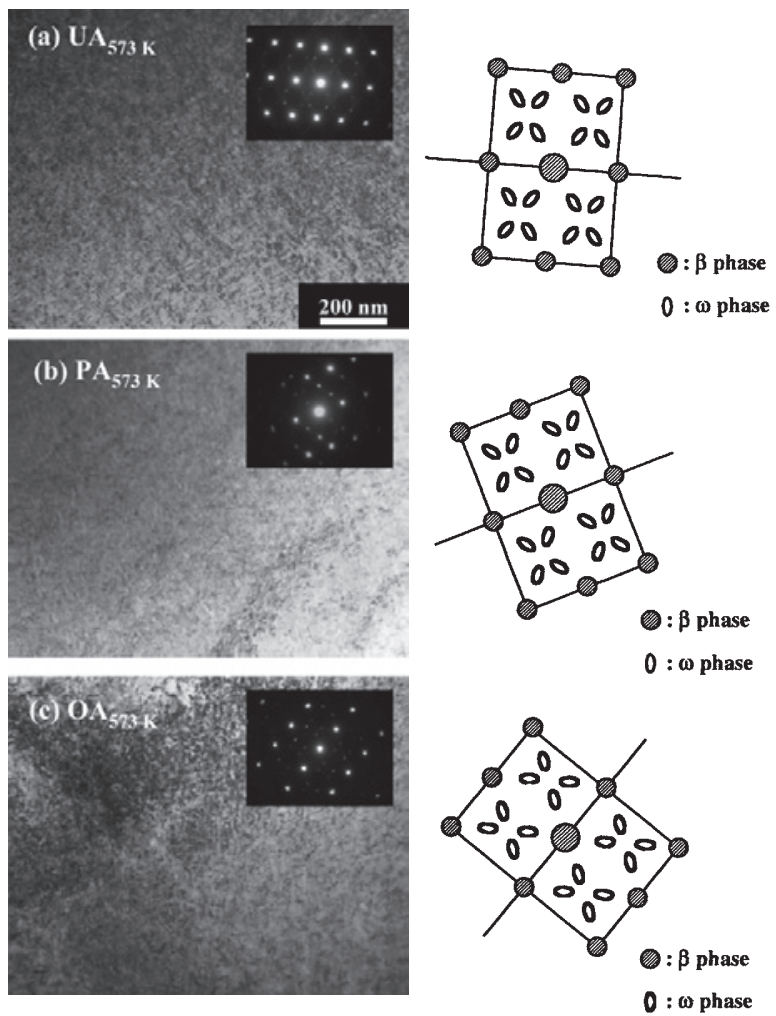

Fig.12 TEM micrographs and key diagrams of (a) $\mathrm{UA}_{573 \mathrm{~K}}$, (b) $\mathrm{PA}_{573 \mathrm{~K}}$ and (c) $\mathrm{OA}_{573 \mathrm{~K}}$. Beam direction is parallel to [110].
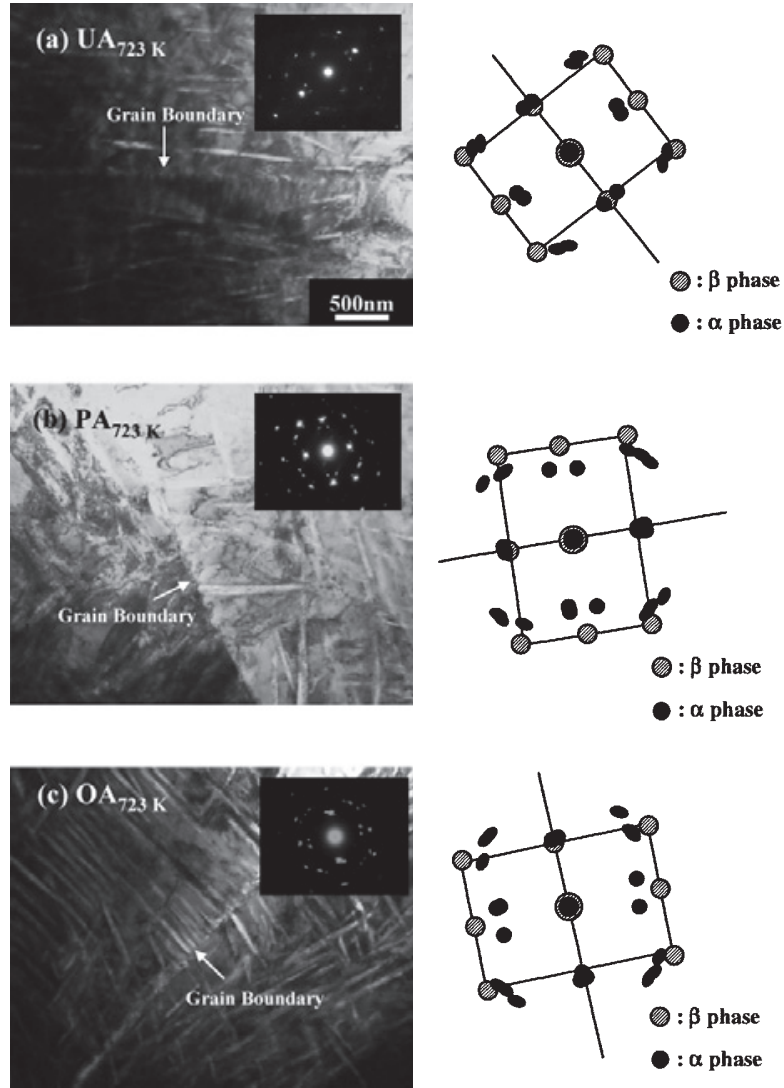

Fig.13 TEM micrographs and key diagrams of (a) $\mathrm{UA}_{723 \mathrm{~K}}$, (b) $\mathrm{PA}_{723 \mathrm{~K}}$ and (c) $\mathrm{OA}_{723} \mathrm{~K}$. Beam direction is parallel to [110].

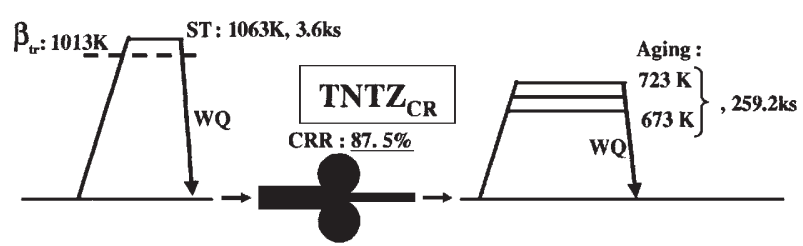

Fig.14 Schematic drawing of thermomechanical processing for TNTZ. ST, WQ and CRR indicate solution treatment, water quenching and cold rolling ratio, respectively.

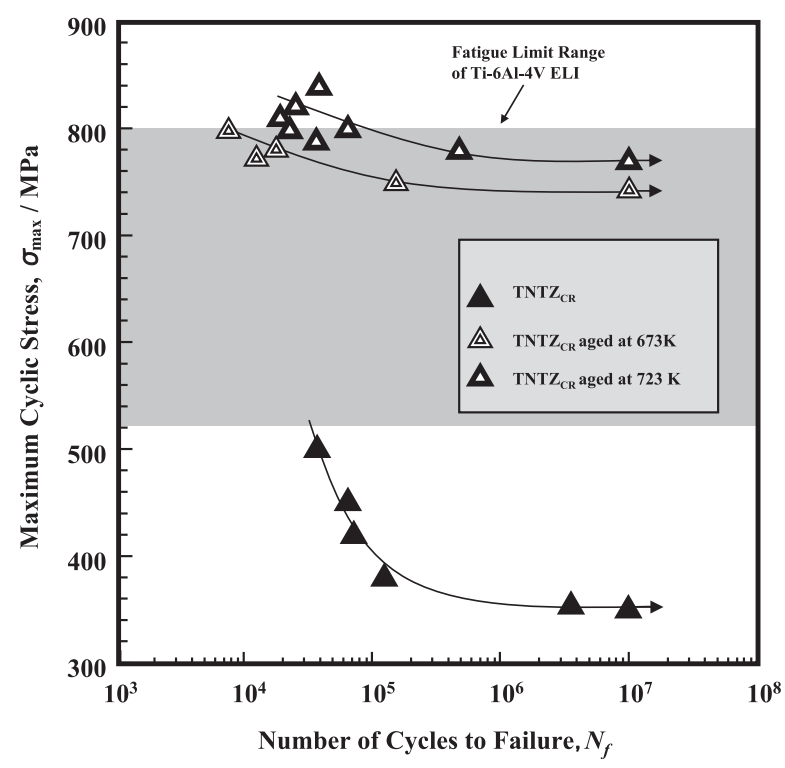

Fig.15 S-N curves of TNTZ in as-solutionized conditions $\left(\right.$ TNTZ $\left._{\mathrm{ST}}\right)$ and as-cold rolled conditions $\left(\mathrm{TNTZ}_{\mathrm{CR}}\right)$, and $\mathrm{TNTZ}_{\mathrm{ST}}$ and TNTZ $_{\mathrm{CR}}$ subjected to aging at $598 \mathrm{~K}, 673 \mathrm{~K}$ and $723 \mathrm{~K}$ for $259.2 \mathrm{ks}$ with fatigue limit range of Ti-6Al-4V ELI in air.

より, その疲労限がTi-6Al-4V 合金のその範囲の上限範囲に 位置するようになる(Fig.15) ${ }^{11)}$. その場合, 強度および延性バ ランスも良好で, 弾性率の上昇があるが, その值は約 $80 \mathrm{GPa}$ でTi-6Al-4V合金の弾性率に比べてかなり低いことも示され ている. そのような場合, $\beta$ 母相に長さ数百ナノオーダーの $\alpha$ 相が均一微細に析出した組織構造となっている.

4.3 フレッテイング疲労

骨プレートおよびネジ, ステムおよび骨等の間では摩擦摩 耗が生じるとともに, 繰返し荷重がかかる, いわゆるフレッ テイング疲労によりインプラント器具が機能しなくなる可能 性が高い。したがって, 金属系生体用材料のフレッテイング 疲労特性は，極めて重要である.

Fig.16 ${ }^{12)}$ にTNTZ合金のST材の大気中および擬似生体内環

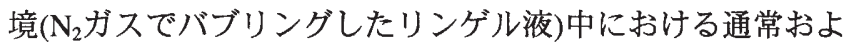
びフレッティング疲労試験で得られた $S-N$ 曲線を示す. TNTZ合金のST材のリンゲル液中での通常疲労強度は, 低サ イクルおよび高サイクル疲労寿命領域において, 大気中のそ れとほぼ同等であり,リンゲル液による顕著な影響を受けな い.しかし, フレッティング疲労強度には, 環境の影響が現 


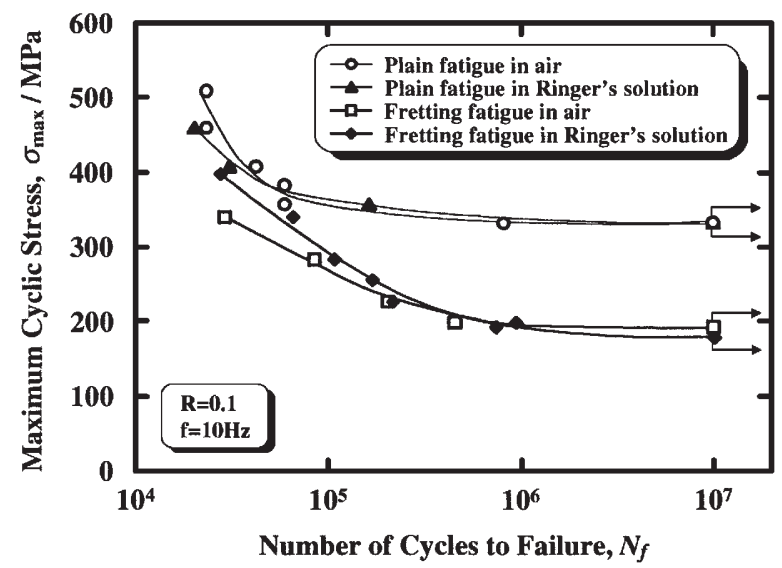

Fig.16 S-N curves of TNTZ subjected to solution treatment obtained from plain fatigue and fretting fatigue tests in air and Ringer's solution

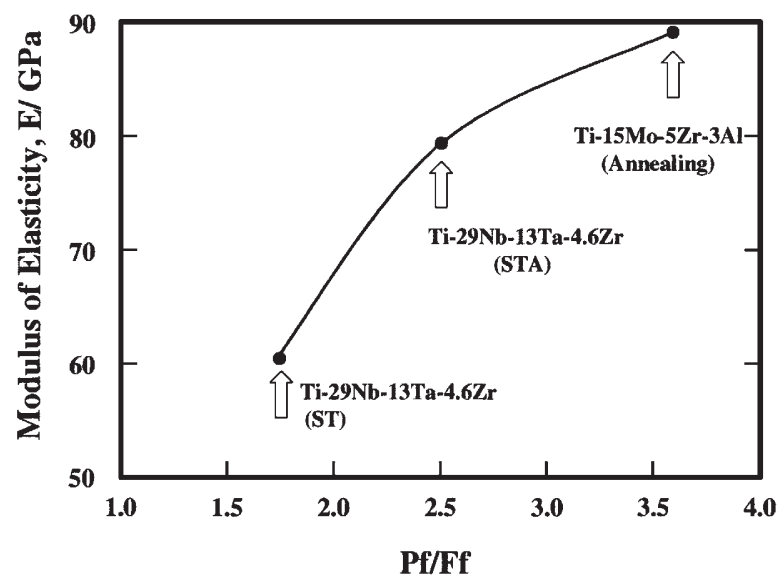

Fig.17 Relationships between fretting damage ratio, Pf/Ff, modulus of elasticity or Vickers hardness; Pf: plain fatigue limit and Ff: fretting fatigue limit.

れ，低サイクルおよび高サイクル疲労寿命領域において異な る傾向を示している. TNTZ合金のST材のリンゲル液中での フレッティング疲労強度は, 大気中のそれと比較して, 低サ イクル疲労寿命領域では若干上昇し, 高サイクル疲労寿命領 域では若干低下する傾向を示している。すなわち，低サイク ル疲労寿命領域ではリンゲル液による潤滑勃果がより大きく, 高サイクル疲労寿命領域ではフレッテイングによる腐食促進 の影響がより大きいためと説明できる.

Fig.17 ${ }^{12)}$ に示すように，フレッテイングによる疲労強度の 低下は, 材料の弾性率が小さい程小さいことも報告されてお り, TNTZ 合金は, フレッテイング疲労の観点からも有利で あると思われる.

\section{4 摩擦摩耗}

チタン合金の摩耗抵抗はCo-Cr合金等に比べて劣っている ことから, 生体用チタン合金では, 耐摩耗性の改善が必要と される.耐摩耗性の改善には, 酸化処理, 窒化処理, PVD/CVD コーティング，溶射法等の表面硬化処理が有効あるが，これ

\section{as $\mathrm{ST}$.6 ks oxidized}

嘈 43.2 ks oxidized $\mathbb{8} 86.4$ ks oxidized

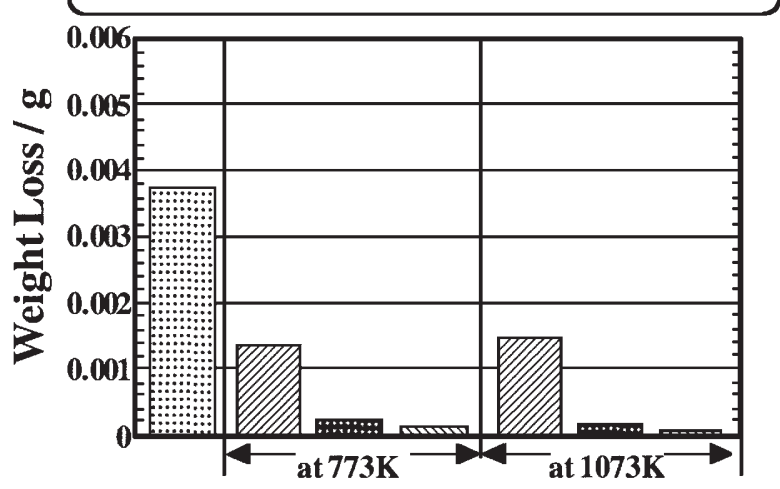

Fig.18 Weight loss of TNTZ in friction wear tests in Ringer's solution. Each alloy was subjected to oxidation at $773 \mathrm{~K}$ and $1073 \mathrm{~K}$ for various time indicated after solution treatment (ST).

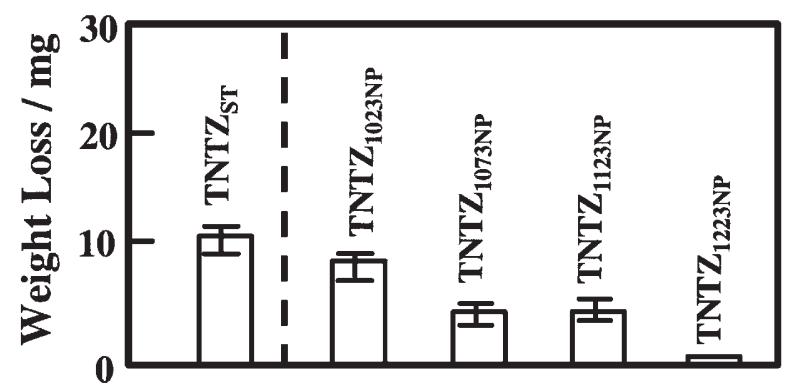

Fig.19 Weight loss of TNTZ subjected to solution treatment, and nitriding obtained from friction wear tests in Ringer's solution.

らの内，酸化処理やガス窒化処理が簡便である.

チタン合金に大気中で酸化処理を施すと, 最表面に $\mathrm{TiO}_{2}$ が 形成されると同時に $\alpha$ 安定化元素である酸素の拡散によりそ の母相側に $\alpha$-ケース ( $\alpha$ 相が多量に析出した領域) も形成さ れる.この領域では, $\alpha$ 相の析出が促進され, 硬さが増大し, 耐摩耗性の改善に慗がる. Fig.18 ${ }^{13)}$ に $773 \mathrm{~K}$ および $1073 \mathrm{~K} に$ て種々の時間酸化処理を施したTNTZ合金のリンゲル液中で の摩擦摩耗試験結果を示す。この場合, 相手材は, ジルコニ アである.いずれの温度での酸化処理でもリンゲル液中での 耐摩耗性が改善されており, さらに酸化処理時間の増加とと もに耐摩耗性が増大することがわかる. また, 長時間の酸化 処理では, $1073 \mathrm{~K}$ での酸化処理で, より耐磨耗性が改善され ている.

一方, Fig.19 ${ }^{14)}$ に溶体化状態のTNTZ合金 $\left(\mathrm{TNTZ}_{\mathrm{ST}}\right)$ に $1023 \mathrm{~K}$, $1073 \mathrm{~K}, 1123 \mathrm{~K}$ および $1223 \mathrm{~K}$ の各温度にてガス窒化処理した 場合 (それぞれ, 図中では TNTZ 1023NP, TNTZ $_{1073 N \mathrm{~N},}, \mathrm{TNTZ}_{1123 \mathrm{NP}}$, $\left.\mathrm{TNTZ}_{1223 \mathrm{NP}}\right)$ のリンゲル液中での摩擦摩耗試験結果を示す。こ の場合も相手材は，ジルコニアである．ガス窒化処理により 
摩擦摩耗抵抗が改善しており, ガス窒化温度の上昇とともに 摩擦摩耗抵抗が上昇している。これうの場合, 表面にTiN お よび $\mathrm{Ti}_{2} \mathrm{~N}$ の硬化層が形成され, 耐摩耗性が向上するが, より 高温でのガス窒化処理ではTiNの割合がより増加し，より耐 摩耗性が改善する。

\section{5 超弾性機能}

TiNi合金が形状記憶特性や超弾性機能に優れるため, ステ ント等を構成するバイオマテリアルとして実用化され, 注目 を浴びているが, 金属アレルギー性の高い $\mathrm{Ni}$ を多量に含有す るため, $\mathrm{Ni}$ フリーで, かつ毒性の指摘のない元素からなる生 体用超弾性あるいは形状記憶チタン合金の研究・開発が活発 化してきている.

TNTZ合金においても冷間強加工と短時間溶体化とを組み 合わせた加工熱処理を施すことにより，Fig.2015)に示すように 超弾性挙動が認められるようになる.このような超弾性挙動 は, 一般的には加工誘起マルテンサイトとその逆変態による が,この場合の超弾性発現機構は, 未だ明確とされていない.

$\mathrm{Ni}$ フリー生体用形状記憶合金として開発され $\beta$ 型チタン合 金は, 多数あり, 例えばTi-Nb-Sn 系合金, Ti-Mo-Ga系合金, Ti-Mo-Ge 系合金, Ti-Mo-Al 系合金, Ti-Nb-Al 系合金, Ti$\mathrm{Ta}$ 系合金, Ti-Nb系合金, Ti-Sc-Mo 系合金, Ti-Mo-Ag-Sn 系合金等が開発されている ${ }^{16,17)}$. 形状記憶 $\beta$ 型チタン合金は, 擬弾性を示すことから, 超弾性挙動も示す. Ti-Nb-Al 系合金 では，集合組織を制御することで, $6.3 \%$ の弾性歪を示すとさ れ, TiNiの弹性歪に匹敵する弾性歪が得られている ${ }^{18)}$.これ らの合金の超弾性や形状記憶発現機構は, 加工誘起マルテン サイとその逆変態である.

\section{6 生体活性表面修飾}

チタン合金は, 生体活性でないため, 生体機能性を高度化 するためには，生体活性表面修飾を施すことが必要である.
骨との直接融合を達成するためになされるハイドロキシアパ タイト表面修飾が盛んである。 その場合, 荷重が負荷された 場合にハイドロキシアパタイト表面修飾層がチタン合金基地 から剥離したり，割れを生じたりする懸念がある．特に，繰 り返し応力が作用する場合は，力学的に厳しい条件である.

著者らは, リン酸カルシウム系結晶化ガラスディプコー ティング法によりTNTZ合金にハイドロキシアパタイト表面 修飾を行っているが ${ }^{199}$ ，その場合には，同合金の溶体化温度 以上の高温での焼成工程が含まれ強度低下を来たすため, 全 プロセス終了後強度を向上させる必要があると時効処理を施 すことがあるので,さらに力学的条件は厳しくなる. Fig.21 20) は, TNTZ合金にリン酸カルシウム系結晶化ガラスコーティ ング層の厚さを $20 \mu \mathrm{m}$ および $5 \mu \mathrm{m}$ にコーティング処理後, $723 \mathrm{~K}$ にて種々の時間時効処理を施した場合のコーティング層の引 張り接着強度を示している. コーティング層の厚さを $5 \mu \mathrm{m}$ と することで, コーティング層の引張り接着強度の低下を防ぐ ことができる. すなわち, コーティング層厚さが $20 \mu \mathrm{m}$ では, 時効処理によりコーティング層の剥離や割れが生じ, $5 \mu \mathrm{m}$ で

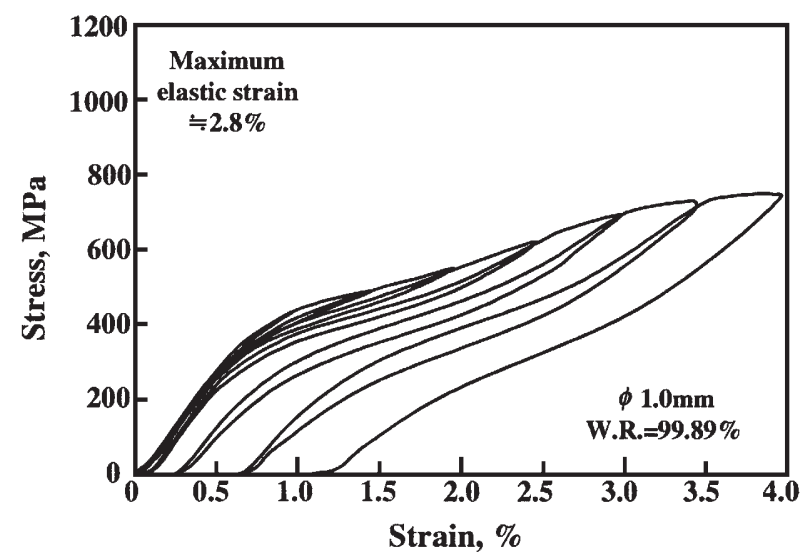

Fig.20 Tensile loading-unloading stress-strain curves of as-cold draw TNTZ $(\phi 1.0 \mathrm{~mm})$. W.R. indicates work ratio.

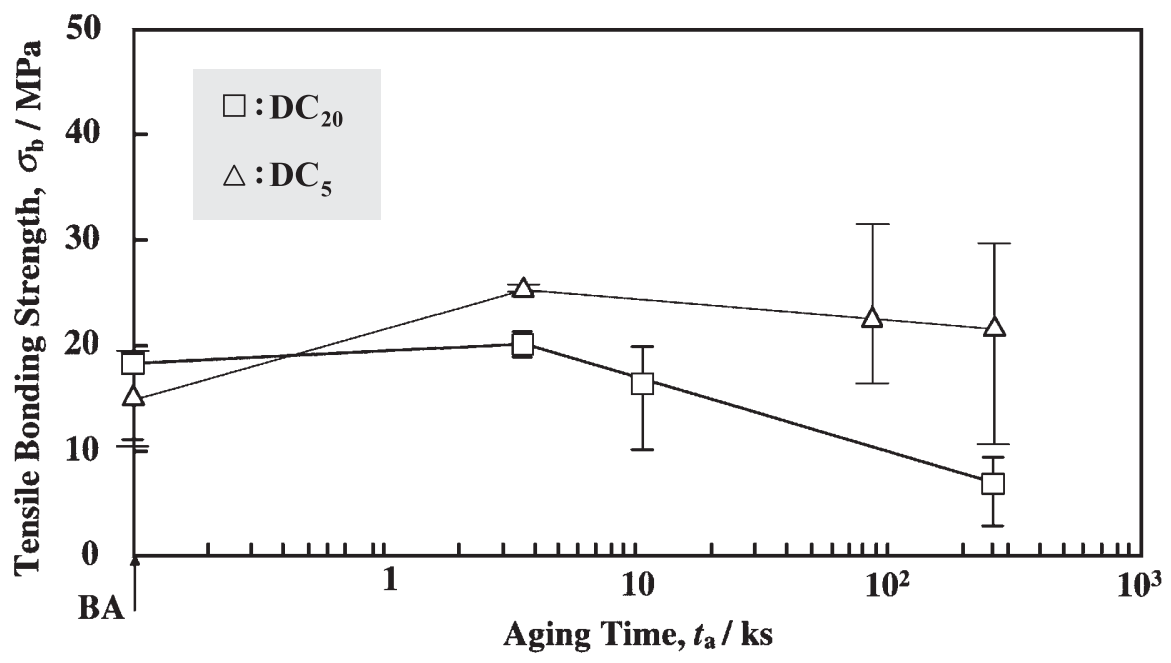

Fig.21 Relationship between tensile bonding strength of calcium phosphate glass-ceramic coating layer with a thickness of $5 \mathrm{~mm}$ (DC5) or $20 \mathrm{~mm}$ (DC20), and aging time in Ti-29Nb-13Ta-4.6Zr. BA indicates before aging. 


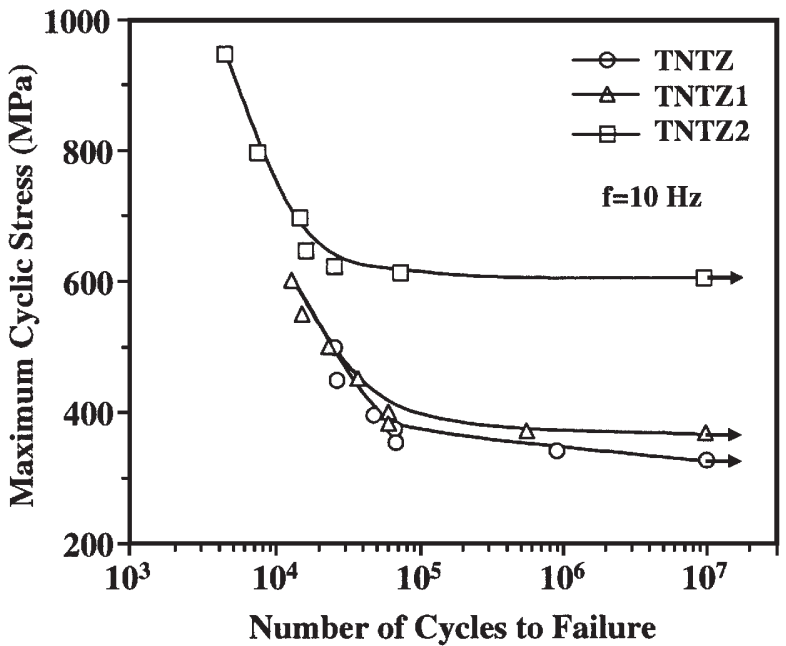

Fig.22 S-N curves of as-solutionized TNTZ, calcium phosphateglass ceramic coated TNTZ (TNTZ1), and aged calcium phosphate-glass ceramic coated TNTZ (TNTZ2).

はそれらが生じないことを示している.

さらに，TNTZ合金につき，コーティング層厚さを $5 \mu \mathrm{m}$ と し種々の時効処理を施した場合の疲労強度試験結果を Fig.22 ${ }^{21)}$ に示す. コーティング处理後時効処理を施すことで 疲労強度が著しく改善されていることがわかる.この時の, 走查型電子顕微鏡(SEM)よる疲労破面写真をFig.23 $3^{21)}$ に示す。 コーティング層の剥離や割れは認められない。このように, コーティング層の厚さを制御することで, 絽り返し応力下で もコーティング層の強固な接着を保つことができる.

また, 他の簡便な生体活性表面修飾法として, アルカリ処 理 22,23$)$ や電気化学処理 ${ }^{24)} も T N T Z$ 合金に対して有効であるが, 純チタンの場合に比べて, 生体活性であるハイドロキシアパ タイトの形成能に劣る点が課題である.

\section{7 おわりに}

本稿では，触れなかったが，低弾性率化に関してはポーラ ス化が, 機能性に関しては高分子との複合化等も精力的に検 討されているなど, 金属, セラミックスおよび高分子を調和 させ,さらに金属系バイオマテリアルの生体機能を高次化が 進められている，その場合の基盤金属バイオマテリアルは, やはりチタンおよびチタン合金が主体なっており，依然とし てその高性能化・高機能化が望まれている. チタン合金のさ らなる低侵襲性化に向けて精力的な研究・開発が展開される ことを期待する.

\section{文献}

1) H.Kawara: "Cytotoxicity of Implantable Metals and Alloys", Bulliten of Japan Insitute of Metals, 31 (1992) 1033-1039.

2) S.G.Steinemann: "Corrosion of Surgical Implants-in vivo and in vitro Tests", Evaluation of Biomaterials, eds. G.D.Winter,

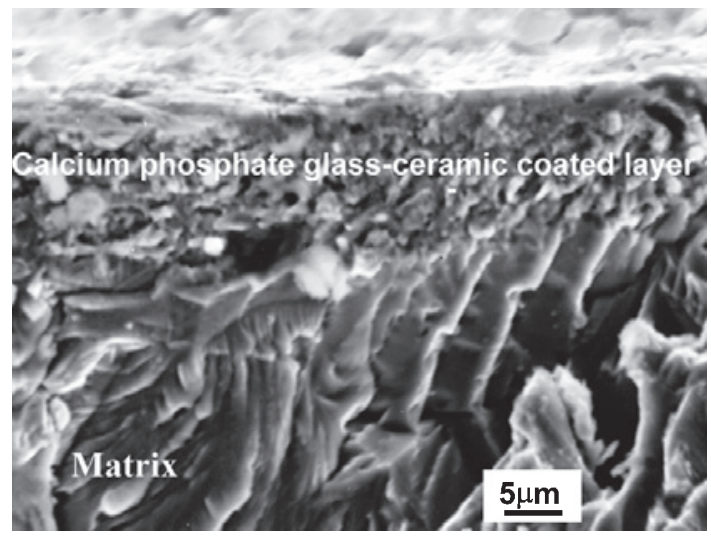

Fig.23 SEM fractograph of calcium phosphate glass-ceramic coated TNTZ (the number of cycles, $\mathrm{N}=557,862$ ).

J.L.Leray, K.De Groot, John Wiley \& Sons Ltd., (1980)1-34.

3) D.Kuroda, M.Ninomi, M.Morinaga, Y.Kato and T.Yashiro: "Design and Mechanical Properties of New Beta Type Titanium Alloys for Implant", Mater. Sci. and Engng. A, A243(1998) 244-249.

4) H.J.Rack and J.I.Qazi: "Titanium Alloys for Biomedical Applications", Mater. Sci. Eng. C, 26(2005)269-1277.

5) T.Saito, T.Furuta, J-H.Hwang, S.Kuramoto, K.Nishino, N.Suzuki, R.Chen, A.Yamada, K.Ito, Y.Seno, T.Nonaka, H.Ikehata, N.Nagasako, C.Iwamoto, Y.Ikuhara and T.Sakuma: "Multifunctional Alloys Obtained via Dislocation-Free Plastic Deformation Mechanism", Science, 300(2003)464-467.

6) M.Niinomi, T.Hattori, K.Morikawa, T.Kasuga, A.Suzuki, H.Fukui and S.Niwa: "Development of Low Rigidity $\beta$-type Titanium Alloy for Biomedical Applications", Mater. Trans., 43(2002)2970-2877.

7) M.Niinomi, T.Hattori and S.Niwa: "Biomaterials in Orthopedics, Material Characteristics and Biocompatibility of Low Rigidity Titanium Alloys for Biomedical Applications", eds. M.J.Yaszemski, D.J.Trantolo, K.U.Lewandrowski, V.Hasirci, D.E.Altobelli and D.L.Wise, Marcel Dekker, INC, (2004)41-62.

8) M.Niinomi, T.Akahori, M.Nakai and T.Hattori: "Low Modukus Multi-Functinal Titanium Alloys for Biomedical Applications", Kinzoku, 77(2007)128-134.

9) N.Sumitomo, K.Noritake, T.Hattori, K.Morikawa, S.Niwa, K.Sato and M.Niinomi: "Experiment Study on Fracture Fixation with Low Rigidity Titanium Alloy- Plate Fixation of Tibia Fracture Model in Rabbit", Proc. 21st European Conference on Biomaterials, Brighton, UK, (2007), to be published.

10) T.Akahori, M.Niinomi, A.Noda, H.Toda, H.Fukui and M.Ogawa: "Effect of Aging Treatment on Mechanical Properties of Ti-29Nb-13Ta-4.6Zr Alloy for Biomedical 
Applications", J. Japan Institute of Metals, 70(2006)295-303.

11) T.Akahori, M.Niinomi, K.Ishimizu, H.Fukui and A.Suzuki: "Effect of Thermomechanical Treatment on Fatigue Characteristics of Ti-29Nb-13Ta-4.6Zr", J. Japan Institute of Metals, 67(2003)652-660.

12) M.Niinomi, T.Akahori, T.Yabunaka, H.Fukui and A.Suzuki: "Fretting Fatigue Characteristics of Newly Developed $\beta$-type Titanium Alloy for Biomedical Appications in Air and Simulated Body Environment", Tetsu-to-Hagane, 88(2002) 553-560.

13) M.Niinomi, T.Akahori, S.Nakamura, H.Fukui and A.Suzuki: "Friction Wear of Surface Oxidized Newly Developed $\beta$-type Titanium Alloy for Biomedical Applications in Simulated Body Environment", Tetsu-to-Hagane, 88(2002)567-574.

14) T.Akahori, M.Niinomi, M.Nakai, H.Nishimura, Y.Takei, H.Fukui and M.Ogawa: "Wear and Mechanical Properties, and Cell Viability of Gas-Nitrided Beta-Type Ti-Nb-Ta-Zr System Alloy for Biomedical Applications", Mater. Trans., 40(2008) 166-174

15) M.Niinomi, T.Akahori, S.Katsura, K.Yamauchi and M.Ogawa: "Mechanical Characteristics and Microstructure of Drwan Wire of Ti-29Nb-13Ta-4.6Zr for Biomedical Applications", Materialc Science and Engineering C, 27(2007)154-161.

16) K.Nitta, S.Watanabe, N.Masahashi, H.Hosoda and S.Hanada: "Ni-free Ti-Nb-Sn Shape Memory Alloys", Structural Biomaterials for the 21 st Century, eds. M.Niinomi, T.Okabe, E.M.Taleff, D.R.Lesure, and H.E.Lippard, (2001)25-34.

17) M.Niinomi: "Recent Research and Development in Titanium Alloys for Biomedical Applications and Healthcare Goods",
Science and Technology for Advanced Materials, 4(2003)445454.

18) H.Hosoda: "Superelastic Titanium Alloys for Biomedical Applications", Front Line of Reserach and Development of Titanium Alloys, Japan Institute of Metals, (2004)9-13.

19) T.Kasuga, M.Nogami, M.Niinomi and T.Hattori: "Bioactive Calcium Phosphate Invert Glass-Ceramic Coating on $\beta$-type Ti-29Nb-13Ta-4.6Zr", Biomaterials, 24(2003)283-290.

20) T.Akahori, M.Niinomi, S.Koyanagi, T.Koyanaga, H.Toda, H.Fukui and M.Ogawa: "Aging Treatment and Mechanical Properties of Calcium Phosphate Glass-ceramic Coated Ti29Nb-13Ta-4.6Zr for Biomedical Applications", J. Japan Institte of Metals, 70(2006)314-321.

21) S.J.Li, M.Niinomi, T.Akahori, T.Kasuga, R.Yang and Y.L.Hao: "Fatigue Characteristics of Bioactive Glass-ceramic Coated Ti29Nb-13Ta-4.6Zr for Biomedical Application", Biomaterials, 25(2004)3341-3349.

22) H.M.Kim, F.Miyaji and T.Kokubo: "Effect of Heat Treatment on Apatite-forming Ability of Ti Metal Induced by Alkali Treatment", J. Materials Science: Materials in Medicine, 8 (1997)341-347.

23) T.Akahori, M.Niinomi, M.Nakai, H.Fukuda, H.Fukui and M.Ogawa: "Bioactive Ceramic Surface Modification of $\beta$-Type Ti-Nb-Ta-Zr System Alloy by Alkai Solution Treatment", Mater. Trans., 48(2007)380-384.

24) M.Niinomi and T.Akahori: "Hybridization of Biomedical Beta Type Titanium Alloy and Bioactive Ceramic by Electrochemical Treatment", Advanced in Technology of Materials and Materials Processing Journal, 9(2007)9-16. 